\title{
Very important pharmacogene summary for VDR
}

\section{Citation}

Poon, Audrey H., Li Gong, Charlotte Brasch-Andersen, Augusto A. Litonjua, Benjamin A. Raby, Qutayba Hamid, Catherine Laprise, Scott T. Weiss, Russ B. Altman, and Teri E. Klein. 2012. Very important pharmacogene summary for VDR. Pharmacogenetics and Genomics 22, no. 10: 758763. doi:10.1097/fpc.0b013e328354455c.

\section{Published Version}

doi:10.1097/FPC.0b013e328354455c

\section{Permanent link}

http://nrs.harvard.edu/urn-3:HUL.InstRepos:27003771

\section{Terms of Use}

This article was downloaded from Harvard University's DASH repository, and is made available under the terms and conditions applicable to Other Posted Material, as set forth at http:// nrs.harvard.edu/urn-3:HUL.InstRepos:dash.current.terms-of-use\#LAA

\section{Share Your Story}

The Harvard community has made this article openly available.

Please share how this access benefits you. Submit a story.

\section{Accessibility}


Published in final edited form as:

Pharmacogenet Genomics. 2012 October ; 22(10): 758-763. doi:10.1097/FPC.0b013e328354455c.

\title{
Very important pharmacogene summary for VDR
}

\author{
Audrey H. Poon a,g,h, Li Gong ${ }^{\mathrm{e}}$, Charlotte Brasch-Anderseni, Augusto A. Litonjua ${ }^{\mathrm{a}, \mathrm{b}, \mathrm{c}}$, \\ Benjamin A. Raby ${ }^{\mathrm{a}, \mathrm{b}}$, Qutayba Hamidg, Catherine Laprise ${ }^{\mathrm{h}}$, Scott T. Weiss ${ }^{\mathrm{a}, \mathrm{c}, \mathrm{d}}$, Russ B. \\ Altman $^{e, f}$, and Teri E. Kleine \\ ${ }^{a}$ Channing Laboratory, Harvard Medical School, Brigham and Women's Hospital, Boston, \\ Massachusetts \\ ${ }^{b}$ Division of Pulmonary and Critical Care Medicine, Harvard Medical School, Brigham and \\ Women's Hospital, Boston, Massachusetts \\ 'The Department of Medicine, Harvard Medical School, Brigham and Women's Hospital, Boston, \\ Massachusetts \\ dThe Partners Center for Personalized Genetic Medicine, Partners HealthCare, Boston, \\ Massachusetts \\ eDepartment of Genetics, Stanford University, Stanford, California, USA \\ fDepartment of Bioengineering, Stanford University, Stanford, California, USA \\ 9Meakins-Christie Laboratories, McGill University Health Centre, Montreal, \\ hDepartment of Fundamental Sciences, University of Quebec at Chicoutimi, Saguenay, Quebec, \\ Canada \\ 'Department of Clinical Genetics, Odense University Hospital, Odense, Denmark
}

\section{Keywords}

drug response; genetic variants; pharmacogenomics; vitamin D receptor

\section{Introduction}

The vitamin D receptor (VDR) binds the active form of vitamin D (1,25-dihydroxyvitamin $\mathrm{D}_{3}$ ). It belongs to the family of trans-acting transcriptional regulatory factors and shows sequence similarity to the steroid and thyroid hormone receptors. The gene was cloned by Baker and colleagues in 1988 and maps to chromosome 12q13.11 [1]. It consists of nine exons with at least six isoforms of exon 1, spans $63.5 \mathrm{~kb}$, and encodes a 427 amino acid protein [2]. Alternative splicing results in multiple transcript variants encoding the VDR protein of different lengths $[3,4]$.

The interaction of 1,25-dihydroxyvitamin $\mathrm{D}_{3}$ with VDR modulates many biological activities of the neural, immune, and endocrine systems, including calcium and phosphorous homeostasis, apoptosis, and cell differentiation (reviewed by Hewison and colleagues [5-7]).

(C) 2012 Wolters Kluwer Health | Lippincott Williams \& Wilkins

Correspondence to Teri E. Klein, PhD, Department of Genetics, Stanford University, 1501 California Avenue, Palo Alto, Stanford,

CA 94304, USA Tel: + 1650725 0659; fax: + 1650725 3863; feedback@ pharmgkb.org.

Conflicts of interest

There are no conflicts of interest. 
Its pleiotropic property is reflected by the findings that VDR is expressed in at least 37 tissues, which can roughly be grouped into seven biological systems (calcium homeostasis, immune, pancreatic $\beta$ cells, muscle, cardiovascular, brain, and lung) [8-10]. The most characterized mechanism is the binding of vitamin $\mathrm{D}_{3}$ to nuclear VDR, which activates the receptor to form a heterodimer with the retinoid-X receptor and interacts with a specific DNA sequence on the gene promoter regions called the 'vitamin D response element' (VDRE). Transcription repressors occupying the VDRE are then replaced by transcription activators to initiate transcription of targeted genes. Microarray analyses using different human cell lines have identified over 100 genes with VDREs in the promoter regions, all potential targets of the 1,25-dihydroxyvitamin $\mathrm{D}_{3}-\mathrm{VDR}$ complex [11-13]. In human oral squamous carcinoma SCC25 cells, genes with characterized VDREs and of which demonstrated greater than 10-fold increase after treatment with 1,25-dihydroxy-vitamin $\mathrm{D}_{3}$ include 24-hydroxylase (CYP24), 17ß-hydroxy-steroid dehydrogenase (HSD17B2), CD14 (CD14), type XIII collagen (COL13A1), and 5-lipoxygenase ( $A L O X 5)$ [13]. The effect of 1,25-dihydroxyvitamin $\mathrm{D}_{3}$ by binding to VDR in the nucleus is often described as the slowacting genomic effect; the effect will take days or hours to be noticed.

Alternatively, 1,25-dihydroxyvitamin $\mathrm{D}_{3}$ can bind to VDR located in the caveolae in the plasma membrane to exert rapid responses through production of second messengers [14]. Pathways that have been shown to be activated by the 1,25-dihydroxyvitamin $\mathrm{D}_{3}-$ $\mathrm{VDR}_{[\mathrm{memb}]}$ complex include mitogen-activated protein kinase-dependent [15], cAMPdependent [16], phospholipase $\mathrm{A}_{2}$-dependent [17], phospholipase C-dependent [18], phosphatidylinositol 3-kinase-dependent [19], and protein kinase C-dependent [20] pathways. Examples of such rapid response include rapid $\mathrm{Ca}^{2+}$ absorption in the duodenum [21,22], opening of $\mathrm{Cl}^{-}$channels and secretion in osteoblasts, insulin secretion from pancreatic $\beta$-cells $[23,24]$, and vascular smooth muscle cell migration [19].

\section{VDR variations}

Because of the pleiotropic effect exerted by the 1,25-dihydroxyvitamin $\mathrm{D}_{3}$-VDR complex, its genetic variants have been found to be associated with a wide variety of diseases/ phenotypes, including various types of cancer, tuberculosis, asthma, height, longevity/ mortality, insulin-dependent diabetes mellitus, bone mineral density (BMD), and hyperparathyroidism, as reviewed comprehensively elsewhere $[25,26]$. This study focuses on clinically relevant associations between treatment responses in the presence of VDR genetic polymorphisms. Furthermore, although no VDR polymorphism has been reported to be associated with vitamin D treatment in cancer therapy, the findings that VDR expression is reduced in colon cancer and negatively correlated with progression imply a role of VDR protein expression in treatment response [27-29].

In a comprehensive study of the genetic architecture of VDR, areas of low linkage disequilibrium (LD) and areas of high LD were observed [30]. This study further noted that the number and size of LD blocks are different in whites, Han Chinese, and Africans. In whites, four blocks were found at the $5^{\prime}$ end, and the largest block encompassed exons 4-9 and 3' UTR. The LD structure in Han Chinese is similar to that of whites but that of African Americans is substantially fragmented and different from that of whites and Han Chinese. The $5^{\prime}$ promoter variants $C d \times 2$ and $G A T A$ reside in block 2, and the three widely studied 3' variants BsmI, ApaI, and TaqI are located in block 5; variant FokI does not reside in any block and is located between blocks 2 and 3. However, further analysis of this genomic area showed that the three variants do not capture all the information in the block [31]. (Note: In the nomenclature of the variants, the alleles are conventionally defined by capital letters in the absence of a restriction site and by small letters in the presence of a given restriction site; for example, TaqI T and $\mathrm{C}$ alleles are named $\mathrm{T}$ and $\mathrm{t}$, respectively. To avoid confusion this 
review will only use the allele corresponding to the nucleic acid.) This review highlights the pharmacogenetic effects of $V D R$ polymorphisms in various biological systems. Table 1 summarizes the functional effect and associated phenotypes of genetic variants in the VDR gene.

\section{Important variants}

\section{5' variants}

VDR: rs11568820 (A > G, commonly known as Cdx2) and rs4516035 ( $\mathrm{T}>\mathrm{C}$, commonly known as GATA)-Two functional variants lying in an LD block in the promoter region captured the genetic information around exons 1e and 1a and are often analyzed as a haplotype block [51]. These two variants are commonly known as $C d \times 2$ (rs11568820) and GATA (rs4516035). Variant rs11568820 resides in the binding site of transcription factor $\mathrm{Cdx} 2$, upstream of exon 1e. Functional analyses showed that the $\mathrm{A}$ to $\mathrm{G}$ base substitution (referring to the minus strand) eliminates the $\mathrm{Cdx}$ binding site and reduces transcriptional activity of VDR to $70 \%$ of the A allele [52,53]. The frequency of allele A ranges from 50\% in Asians to $80 \%$ in Europeans to $98 \%$ in Sub-Saharan Africans, as estimated by the HapMap Project [54]. Downstream is variant rs4516035, which resides at the GATA binding site, and its $\mathrm{C}$ allele eliminates the GATA binding site and confers a lower VDR promoter activity [51]. The frequency of allele T ranges from 50\% in Europeans to $98 \%$ in Asians to $99 \%$ in Sub-Saharan Africans [54]. Allele Tof GATA is found to have a 1.9-fold higher VDR promoter activity compared with allele C [51]. In a study on 69 Dutch children with acute lymphoblastic leukemia, the effect of dexamethasone treatment on body composition was investigated. It was found that, during treatment, noncarriers of haplotype $C d \times 2$ allele A/GATA allele $\mathrm{C}$ had greater fat gain and higher BMD and apparent BMD of the lumbar spine compared with the carriers [32]. In another study that examined the effect of VDR polymorphisms on growth and treatment response of 1a-hydroxyvitamin D3 derivatives, vitamin $\mathrm{D} 3$, and phosphates to $\mathrm{X}$-linked hypophosphatemic rickets, patients who were treated with 1a-hydroxyvitamin D3 since childhood experienced less growth defect compared with those not treated with 1a-hydroxyvitamin D3 [33]. When the Cdx2/GATA haplotypes of these patients were considered, patients who had been treated with $1 \mathrm{a}$ hydroxyvitamin D3 since childhood and were carriers of $C d \times 2 \mathrm{G} / G A T A$ C haplotype experienced less growth defect compared with noncarriers. In children receiving $1 \mathrm{a}-$ hydroxyvitamin D3 and who were carriers of $C d \times 2 \mathrm{G} / G A T A \mathrm{C}$ haplotype, a lower urinary calcium/creatinine level was detected compared with noncarriers, suggesting that $C d \times 2 \mathrm{G} /$ $G A T A \mathrm{C}$ may protect these children from developing hypercalciuria during treatment. Taken together, these studies showed that carriers of $C d \times 2 \mathrm{G} / G A T A \mathrm{C}$ and $C d \times 2 \mathrm{G} / G A T A$ $T$ haplotypes were at lower risk of having bone-related side effects from treatment with 1ahydroxyvitamin D3 and dexamethasone.

In a recent study that examined the effect of $V D R$ genotypes, calcium intake, and prostate cancer in African Americans, carriers of the $C d \times 2$ GG genotype were found to be at a lower risk (roughly $40 \%$ of men of AA genotype) of developing advanced cancer, and such risk was further reduced (8\% of men of AA genotype) when coupled with a low-calcium diet [34]. The authors noted that the same association was not observed with localized prostate cancer, suggesting that high calcium intake is not involved in the initiation but progression of prostate cancer.

VDR: rs2228570 (T > C, commonly known as Fokl)—At the translation start site of $V D R$, a $\mathrm{T}>\mathrm{C}$ base change of variant rs 2228570 eliminates the translation start site in exon 2 , and the encoded protein is shortened by three amino acids [55]. The frequency of allele T ranges from $40 \%$ in whites and Asians to $20 \%$ in Sub-Saharan Africans [54]. The smaller protein exhibits greater transcription activity because of its greater binding efficiency to 
transcription factor IIB [56]. In immune cells, transcripts with the $\mathrm{C}$ allele (often referred to as allele F of FokI polymorphism) demonstrated stronger transcriptional effect of VDR target genes [57]. Given the pivotal role of 1,25-dihydroxyvitamin $\mathrm{D}_{3}$ and calcium absorption, variant Fok has been studied for its association with calcium absorption, BMD, and other anthropometric measures. In an association study of calcium absorption kinetics, bone mineralization rates, and VDR polymorphisms in early pubertal adolescents, individuals with the TT genotype had less total calcium absorption, and less calcium accretion to the skeleton [36]. In an earlier study, children with the TT genotype were found to have lower calcium absorption and lower BMD, after adjusting for age, ethnicity, BMI, and puberty status [37]. In a study on 36 white postmenopausal women with osteoporosis or osteopenia who were treated with calcium and vitamin D supplements for 3 months, the FokI TC genotype was more common in responders compared with nonresponders [38].

In a study that examined the genotypic effect of $V D R$ polymorphism and calcipotriol response in white psoriasis patients, variant FokI alone was not associated with any significant effect; however, when analyzed in combination with variant $C d \times 2$, patients with the $C d \times 2 \mathrm{AA} / F o k I C C$ genotype combination were four times more likely to respond to calcipotriol [35]. Furthermore, additional variant combinations found to be associated with calcipotriol response were $C d \times 2 \mathrm{AA} / \mathrm{Ta}$ I TT and FokI CC/TaqI TT. A similar association with positive response to calcipotriol in psoriasis patients was detected in a Turkish population [42].

In a study that examined the VDR genetic effect on treatment response of antimycobacterial chemotherapy against tuberculosis in Peruvian patients, carriers of the Fok CC genotype had faster conversion of sputum mycobacterial culture from positive to negative compared with non-CC genotype carriers [39].

In an in-vitro study on thyroid cancer, thyroid cancer cell lines that had significant decrease in cell viability after VDR agonist treatment were found to be those carrying the Fok TT genotype, whereas those of CC genotype were resistant [40]. Further analysis of the mRNA level of 1a-hydroxylase (CYP27BI) and 24-hydroxylase (CYP24AI) suggested that the $\mathrm{C}$ allele may confer resistance by upregulation of 24-hydroxylase and subsequent suppression on VDR activation. However, in an in-vitro study on breast cancer, carriers of the CC genotype were found to have the greatest growth inhibition compared with the TT genotype and vector control after treatment with 1,25-dihydroxy-vitamin $\mathrm{D}_{3}$ [41]. VDR protein level was found to be elevated in the CC, TT genotype carriers and vector control, with CC genotype carriers exhibiting the highest elevation. CYP24A1, a downstream target gene, was upregulated at both the mRNA and protein levels after 1,25-dihydroxyvitamin $\mathrm{D}_{3}$ treatment, with the $\mathrm{CC}$ genotype carriers exhibiting the greatest elevation. In contrast, the protein level of another downstream target, estrogen receptor a (ESRI), was downregulated after treatment, and cells with the CC genotype exhibited the greatest protein suppression. Furthermore, estrogen-induced cell growth was inhibited by 1,25 -dihydroxyvitamin $\mathrm{D}_{3}$ in the cells with the CC genotype but not in the TT genotype counterparts. In the same study the authors demonstrated greater VDR protein stability and longer half-life after 1,25dihydroxy-vitamin $\mathrm{D}_{3}$ treatment in cells carrying the $\mathrm{CC}$ genotype compared with vector control and the TT counterparts.

\section{3' variants}

VDR: rs1544410 (C > T, commonly known as Bsml)-This variant is commonly known as $B s m I$ and is located in intron 8 (allele $\mathrm{C}$ is commonly referred to as allele $\mathrm{b}$ and allele $\mathrm{T}$ is referred as allele $\mathrm{B}$ ). No known functional consequence of this variant has been described; however, a few studies have found that it is associated with antiresorptive treatment responses $[40,41,47,48]$. In a study on the effectiveness of antiresorptive treatment 
in postmenopausal women, treatment outcomes (i.e. BMD, bone formation and bone resorption) were found to be influenced by treatment arms, genotype at variant BsmI and treatment arms $\times$ genotype interactions [47]. Women with the CC genotype had greater improvement in BMD after treatment compared with those with the TT genotype, regardless of the treatment arms. Decrease in bone formation after treatment was the least in $\mathrm{CC}$ women compared with their CTand TTcounterparts. Homozygous CC women also demonstrated the least decrease in bone resorption compared with the other two genotype groups. In a pilot study on antiresorptive treatment (oral alendronate vs. subcutaneous teriparatide) in postmenopausal women, women who received alendronate and had at least one allele $\mathrm{C}$ had greater BMD at their lumbar spine compared with those with the TT genotype [48]. In addition to a genotypic effect toward antiresorptive treatment, BsmI is also associated with response to calcium and vitamin D supplementation in healthy adolescent girls [58]. In a study on 167 adolescent girls from Lebanon, placebo and vitamin D supplements were given randomly for a year, and bone mineral content (BMC), BMD, and lean mass were measured as outcomes [45]. In the treatment group, percentage change in $\mathrm{BMC}$ of the total body, hip, and trochanter were significantly greater in CT heterozygous individuals compared with CT nontreated controls. A similar trend was observed in CC girls, although it did not reach statistical significance. In a study that investigated the effect of longterm antiepileptic treatment on BMD in men and premenopausal women, those with the CC genotypes had higher BMD, higher serum level of 25-hydroxyvitamin $\mathrm{D}_{3}$, and lower level of parathormone, compared with those with the CT and TT genotypes [49].

VDR: rs7975232 (C > A, commonly known as Apal)-This variant is commonly known as ApaI and is located in intron 8 (allele $\mathrm{A}$ is often referred to as allele A and allele C is allele a). At present, no known functional consequence of this variant has been described. In a study that investigated the effect of dairy intake and colorectal cancer recurrence, an interaction between ApaI genotype and dairy product intake was detected [50]. In particular, individuals with at least one copy of allele A and who consumed a large amount of dairy products had the lowest risk of colorectral cancer recurrence compared with CC genotype carriers who consumed lower amounts of dairy products.

VDR: rs731236 (T > C, commonly known as Taql)-This variant is commonly known as TaqI and is located in exon 9 (allele $\mathrm{T}$ is often referred to as allele $\mathrm{T}$, and allele $\mathrm{C}$ is allele t). In a study on tuberculosis susceptibility, it has been demonstrated in lymphoblastoid cell lines that this variant resides on a $\mathrm{CpG}$ island and the $\mathrm{C}$ allele is always methylated, and that interactions exist between $T a q$ I polymorphism, methylation levels, ethnicities, and tuberculosis susceptibility [43].

In a multivariate study investigating the interaction between therapy and VDR variants, allele $\mathrm{C}$ confers increased risk to new fracture in postmenopausal women treated with calcium supplement in Australia [44]. Healthy adolescent girls with the TT genotype had greater spine and femoral neck BMC and femoral neck area when given vitamin D supplement, compared with the CC group [45]. In a study using narrowband ultraviolet light to treat chronic plaque psoriasis, individuals with the CC genotype had the shortest remission period compared with the other genotypes [46]. In another study that examined the VDR genetic effect on treatment response of antimycobacterial chemotherapy against tuberculosis in Peruvian patients, variant FokI CC and TaqI CT genotypes were both found to be associated with faster conversion of sputum mycobacterial culture from positive to negative [39]. 


\section{Conclusion}

The pleiotropic effects of 1,25-dihydroxyvitamin $\mathrm{D}_{3}$ on a wide range of physiological systems render its receptor VDR an attractive candidate for investigation in disease mechanism and therapeutic responses. Of the six conventionally investigated variants, those at the $5^{\prime}$ end have the biological consequence of the base change characterized. Recently, the biological effect of the base change at the TaqI variant was also characterized as aforementioned. It is likely that the associations observed for variants BsmI and ApaI are due to linkage disequilibrium with the causative variant(s). Given the vast number of genes whose transcription can be upregulated or downregulated by VDR, an allele may be a risk factor for one trait and a protective one for another. Although the scientific community agrees that the present guidelines for vitamin D intake must be augmented, one must take into account the differential activity of the VDR protein as partially dictated by variations in the $V D R$ gene.

This PharmGKB summary briefly discusses the very important pharmacogene VDR and its variants that can influence drug responses. A fully interactive version of this short review, with links to individual paper and detailed mapping information, can be found at http:// www.pharmgkb.org/search/annotatedGene/vdr/index.jsp.

\section{References}

1. Baker AR, McDonnell DP, Hughes M, Crisp TM, Mangelsdorf DJ, Haussler MR, et al. Cloning and expression of full-length cDNA encoding human vitamin D receptor. Proc Natl Acad Sci USA. 1988; 85:3294-3298. [PubMed: 2835767]

2. Miyamoto K, Kesterson RA, Yamamoto H, Taketani Y, Nishiwaki E, Tatsumi S, et al. Structural organization of the human vitamin D receptor chromosomal gene and its promoter. Mol Endocrinol. 1997; 11:1165-1179. [PubMed: 9212063]

3. Crofts LA, Hancock MS, Morrison NA, Eisman JA. Multiple promoters direct the tissue-specific expression of novel N-terminal variant human vitamin D receptor gene transcripts. Proc Natl Acad Sci USA. 1998; 95:10529-10534. [PubMed: 9724737]

4. Gardiner EM, Esteban LM, Fong C, Allison SJ, Flanagan JL, Kouzmenko AP, et al. Vitamin D receptor B1 and exon 1d: functional and evolutionary analysis. J Steroid Biochem Mol Biol. 2004; 89-90:233-238. [PubMed: 15225777]

5. Hewison M. Vitamin D and the immune system: new perspectives on an old theme. Endocrinol Metab Clin North Am. 2010; 39:365-379. [PubMed: 20511058]

6. Plum LA, DeLuca HF. Vitamin D, disease and therapeutic opportunities. Nat Rev Drug Discov. 2010; 9:941-955. [PubMed: 21119732]

7. Bikle DD. Vitamin D: an ancient hormone. Exp Dermatol. 2011; 20:7-13. [PubMed: 21197695]

8. Bouillon R, Okamura WH, Norman AW. Structure-function relationships in the vitamin D endocrine system. Endocr Rev. 1995; 16:200-257. [PubMed: 7781594]

9. Nguyen M, Trubert CL, Rizk-Rabin M, Rehan VK, Besancon F, Cayre YE, et al. 1,25Dihydroxyvitamin D3 and fetal lung maturation: immunogold detection of VDR expression in pneumocytes type II cells and effect on fructose 1,6 bisphosphatase. J Steroid Biochem Mol Biol. 2004; 89:90-93.

10. Menezes RJ, Cheney RT, Husain A, Tretiakova M, Loewen G, Johnson CS, et al. Vitamin D receptor expression in normal, premalignant, and malignant human lung tissue. Cancer Epidemiol Biomarkers Prev. 2008; 17:1104-1110. [PubMed: 18483332]

11. Lin R, Nagai Y, Sladek R, Bastien Y, Ho J, Petrecca K, et al. Expression profiling in squamous carcinoma cells reveals pleiotropic effects of vitamin D3 analog EB1089 signaling on cell proliferation, differentiation, and immune system regulation. Mol Endocrinol. 2002; 16:12431256. [PubMed: 12040012] 
12. Wood RJ, Tchack L, Angelo G, Pratt RE, Sonna LA. DNA microarray analysis of vitamin Dinduced gene expression in a human colon carcinoma cell line. Physiol Genomics. 2004; 17:122129. [PubMed: 14996990]

13. Wang TT, Tavera-Mendoza LE, Laperriere D, Libby E, MacLeod NB, Nagai Y, et al. Large-scale in silico and microarray-based identification of direct 1,25-dihydroxyvitamin D3 target genes. Mol Endocrinol. 2005; 19:2685-2695. [PubMed: 16002434]

14. Huhtakangas JA, Olivera CJ, Bishop JE, Zanello LP, Norman AW. The vitamin D receptor is present in caveolae-enriched plasma membranes and binds 1 alpha,25(OH)2-vitamin D3 in vivo and in vitro. Mol Endocrinol. 2004; 18:2660-2671. [PubMed: 15272054]

15. Song X, Bishop JE, Okamura WH, Norman AW. Stimulation of phosphorylation of mitogenactivated protein kinase by 1alpha,25-dihydroxyvitamin D3 in promyelocytic NB4 leukemia cells: a structure-function study. Endocrinology. 1998; 139:457-465. [PubMed: 9449611]

16. Massheimer V, Boland R, de Boland AR. Rapid 1,25(OH)2-vitamin D3 stimulation of calcium uptake by rat intestinal cells involves a dihydropyridine-sensitive cAMP-dependent pathway. Cell Signal. 1994; 6:299-304. [PubMed: 7917787]

17. Boyan BD, Sylvia VL, Curry D, Chang Z, Dean DD, Schwartz Z. Arachidonic acid is an autocoid mediator of the differential action of 1,25-(OH)2D3 and 24,25-(OH)2D3 on growth plate chondrocytes. J Cell Physiol. 1998; 176:516-524. [PubMed: 9699504]

18. Khare S, Bolt MJ, Wali RK, Skarosi SF, Roy HK, Niedziela S, et al. 1,25 dihydroxyvitamin D3 stimulates phospholipase C-gamma in rat colonocytes: role of c-Src in PLC-gamma activation. J Clin Invest. 1997; 99:1831-1841. [PubMed: 9109427]

19. Rebsamen MC, Sun J, Norman AW, Liao JK. 1 alpha,25-dihydroxyvitamin D3 induces vascular smooth muscle cell migration via activation of phosphatidylinositol 3-kinase. Circ Res. 2002; 91:17-24. [PubMed: 12114317]

20. Beno DW, Brady LM, Bissonnette M, Davis BH. Protein kinase C and mitogen-activated protein kinase are required for 1,25-dihydroxyvitamin D3-stimulated Egr induction. J Biol Chem. 1995; 270:3642-3647. [PubMed: 7876102]

21. Nemere I, Yoshimoto Y, Norman AW. Calcium transport in perfused duodena from normal chicks: enhancement within fourteen minutes of exposure to 1,25-dihydroxyvitamin D3. Endocrinology. 1984; 115:1476-1483. [PubMed: 6548181]

22. Norman AW, Okamura WH, Hammond MW, Bishop JE, Dormanen MC, Bouillon R, et al. Comparison of 6-s-cis- and 6-s-trans-locked analogs of 1alpha,25-dihydroxyvitamin D3 indicates that the 6-s-cis conformation is preferred for rapid nongenomic biological responses and that neither 6-s-cis-nor 6-s-trans-locked analogs are preferred for genomic biological responses. Mol Endocrinol. 1997; 11:1518-1531. [PubMed: 9280067]

23. Kajikawa M, Ishida H, Fujimoto S, Mukai E, Nishimura M, Fujita J, et al. An insulinotropic effect of vitamin $\mathrm{D}$ analog with increasing intracellular $\mathrm{Ca}^{2+}$ concentration in pancreatic beta-cells through nongenomic signal transduction. Endocrinology. 1999; 140:4706-4712. [PubMed: 10499529]

24. Kadowaki S, Norman AW. Time course study of insulin secretion after 1,25-dihydroxyvitamin D3 administration. Endocrinology. 1985; 117:1765-1771. [PubMed: 3899614]

25. Uitterlinden AG, Fang Y, van Meurs JB, Pols HA, Van Leeuwen JP. Genetics and biology of vitamin D receptor polymorphisms. Gene. 2004; 338:143-156. [PubMed: 15315818]

26. Valdivielso JM, Fernandez E. Vitamin D receptor polymorphisms and diseases. Clin Chim Acta. 2006; 371:1-12. [PubMed: 16563362]

27. Larriba MJ, Bonilla F, Munoz A. The transcription factors Snail1 and Snail2 repress vitamin D receptor during colon cancer progression. J Steroid Biochem Mol Biol. 2010; 121:106-109. [PubMed: 20138990]

28. Palmer HG, Larriba MJ, Garcia JM, Ordonez-Moran P, Pena C, Peiro S, et al. The transcription factor SNAIL represses vitamin D receptor expression and responsiveness in human colon cancer. Nat Med. 2004; 10:917-919. [PubMed: 15322538]

29. Pena C, Garcia JM, Silva J, Garcia V, Rodriguez R, Alonso I, et al. E-cadherin and vitamin D receptor regulation by SNAIL and ZEB1 in colon cancer: clinicopathological correlations. Hum Mol Genet. 2005; 14:3361-3370. [PubMed: 16203744] 
30. Fang Y, van Meurs JB, d'Alesio A, Jhamai M, Zhao H, Rivadeneira F, et al. Promoter and 3' untranslated-region haplotypes in the vitamin $\mathrm{D}$ receptor gene predispose to osteoporotic fracture: the Rotterdam study. Am J Hum Genet. 2005; 77:807-823. [PubMed: 16252240]

31. Nejentsev S, Godfrey L, Snook H, Rance H, Nutland S, Walker NM, et al. Comparative highresolution analysis of linkage disequilibrium and tag single nucleotide polymorphisms between populations in the vitamin D receptor gene. Hum Mol Genet. 2004; 13:1633-1639. [PubMed: 15175274]

32. Te Winkel ML, van Beek RD, de Muinck Keizer-Schrama SM, Uitterlinden AG, Hop WC, Pieters $\mathrm{R}$, et al. Pharmacogenetic risk factors for altered bone mineral density and body composition in pediatric acute lymphoblastic leukemia. Haematologica. 2010; 95:752-759. [PubMed: 20015871]

33. Jehan F, Gaucher C, Nguyen TM, Walrant-Debray O, Lahlou N, Sinding C, et al. Vitamin D receptor genotype in hypophosphatemic rickets as a predictor of growth and response to treatment. J Clin Endocrinol Metab. 2008; 93:4672-4682. [PubMed: 18827005]

34. Rowland GW, Schwartz GG, John EM, Ingles SA. Calcium intake and prostate cancer among African Americans: effect modification by vitamin D receptor calcium absorption genotype. $\mathrm{J}$ Bone Miner Res. 2011 Epub ahead of print.

35. Halsall JA, Osborne JE, Pringle JH, Hutchinson PE. Vitamin D receptor gene polymorphisms, particularly the novel A-1012G promoter polymorphism, are associated with vitamin D3 responsiveness and non-familial susceptibility in psoriasis. Pharmacogenet Genomics. 2005; 15:349-355. [PubMed: 15864137]

36. Abrams SA, Griffin IJ, Hawthorne KM, Chen Z, Gunn SK, Wilde M, et al. Vitamin D receptor Fok1 polymorphisms affect calcium absorption, kinetics, and bone mineralization rates during puberty. J Bone Miner Res. 2005; 20:945-953. [PubMed: 15883634]

37. Ames SK, Ellis KJ, Gunn SK, Copeland KC, Abrams SA. Vitamin D receptor gene Fok1 polymorphism predicts calcium absorption and bone mineral density in children. J Bone Miner Res. 1999; 14:740-746. [PubMed: 10320522]

38. Elnenaei MO, Chandra R, Mangion T, Moniz C. Genomic and metabolomic patterns segregate with responses to calcium and vitamin D supplementation. Br J Nutr. 2011; 105:71-79. [PubMed: 20727239]

39. Roth DE, Soto G, Arenas F, Bautista CT, Ortiz J, Rodriguez R, et al. Association between vitamin $\mathrm{D}$ receptor gene polymorphisms and response to treatment of pulmonary tuberculosis. J Infect Dis. 2004; 190:920-927. [PubMed: 15295697]

40. Sharma V, Fretwell D, Crees Z, Kerege A, Klopper JP. Thyroid cancer resistance to vitamin D receptor activation is associated with 24-hydroxylase levels but not the ff FokI polymorphism. Thyroid. 2010; 20:1103-1111. [PubMed: 20860424]

41. Alimirah F, Peng X, Murillo G, Mehta RG. Functional significance of vitamin D receptor FokI polymorphism in human breast cancer cells. PLoS One. 2011; 6:e16024. [PubMed: 21283672]

42. Dayangac-Erden D, Karaduman A, Erdem-Yurter H. Polymorphisms of vitamin D receptor gene in Turkish familial psoriasis patients. Arch Dermatol Res. 2007; 299:487-491. [PubMed: 17763859]

43. Andraos C, Koorsen G, Knight JC, Bornman L. Vitamin D receptor gene methylation is associated with ethnicity, tuberculosis, and TaqI polymorphism. Hum Immunol. 2011; 72:262-268. [PubMed: 21168462]

44. Morrison NA, George PM, Vaughan T, Tilyard MW, Frampton CM, Gilchrist NL. Vitamin D receptor genotypes influence the success of calcitriol therapy for recurrent vertebral fracture in osteoporosis. Pharmacogenet Genomics. 2005; 15:127-135. [PubMed: 15861036]

45. Arabi A, Zahed L, Mahfoud Z, El-Onsi L, Nabulsi M, Maalouf J, et al. Vitamin D receptor gene polymorphisms modulate the skeletal response to vitamin D supplementation in healthy girls. Bone. 2009; 45:1091-1097. [PubMed: 19647104]

46. Ryan C, Renfro L, Collins P, Kirby B, Rogers S. Clinical and genetic predictors of response to narrowband ultraviolet B for the treatment of chronic plaque psoriasis. Br J Dermatol. 2010; 163:1056-1063. [PubMed: 20716226]

47. Palomba S, Orio F Jr. Russo T, Falbo A, Tolino A, Manguso F, et al. BsmI vitamin D receptor genotypes influence the efficacy of antiresorptive treatments in postmenopausal osteoporotic 
women. A 1-year multicenter, randomized and controlled trial. Osteoporos Int. 2005; 16:943-952. [PubMed: 15739035]

48. Creatsa M, Pliatsika P, Kaparos G, Antoniou A, Armeni E, Tsakonas E, et al. The effect of vitamin D receptor BsmI genotype on the response to osteoporosis treatment in postmenopausal women: a pilot study. J Obstet Gynaecol Res. 2011; 37:1415-1422. [PubMed: 21651652]

49. Lambrinoudaki I, Kaparos G, Armeni E, Alexandrou A, Damaskos C, Logothetis E, et al. BsmI vitamin D receptor's polymorphism and bone mineral density in men and premenopausal women on long-term antiepileptic therapy. Eur J Neurol. 2011; 18:93-98. [PubMed: 20500803]

50. Hubner RA, Muir KR, Liu JF, Logan RF, Grainge MJ, Houlston RS. Dairy products, polymorphisms in the vitamin $\mathrm{D}$ receptor gene and colorectal adenoma recurrence. Int $\mathrm{J}$ Cancer. 2008; 123:586-593. [PubMed: 18470879]

51. D'Alesio A, Garabedian M, Sabatier JP, Guaydier-Souquieres G, Marcelli C, Lemacon A, et al. Two single-nucleotide polymorphisms in the human vitamin D receptor promoter change proteinDNA complex formation and are associated with height and vitamin D status in adolescent girls. Hum Mol Genet. 2005; 14:3539-3548. [PubMed: 16210379]

52. Arai H, Miyamoto KI, Yoshida M, Yamamoto H, Taketani Y, Morita K, et al. The polymorphism in the caudal-related homeodomain protein $\mathrm{Cdx}-2$ binding element in the human vitamin $\mathrm{D}$ receptor gene. J Bone Miner Res. 2001; 16:1256-1264. [PubMed: 11450701]

53. Yamamoto H, Miyamoto K, Li B, Taketani Y, Kitano M, Inoue Y, et al. The caudal-related homeodomain protein $\mathrm{Cdx}-2$ regulates vitamin $\mathrm{D}$ receptor gene expression in the small intestine. $\mathrm{J}$ Bone Miner Res. 1999; 14:240-247. [PubMed: 9933478]

54. International HapMap Consortium. The International HapMap Project. Nature. 2003; 426:789796. [PubMed: 14685227]

55. Saijo T, Ito M, Takeda E, Huq AH, Naito E, Yokota I, et al. A unique mutation in the vitamin D receptor gene in three Japanese patients with vitamin D-dependent rickets type II: utility of singlestrand conformation polymorphism analysis for heterozygous carrier detection. Am J Hum Genet. 1991; 49:668-673. [PubMed: 1652893]

56. Jurutka PW, Remus LS, Whitfield GK, Thompson PD, Hsieh JC, Zitzer H, et al. The polymorphic $\mathrm{N}$ terminus in human vitamin $\mathrm{D}$ receptor isoforms influences transcriptional activity by modulating interaction with transcription factor IIB. Mol Endocrinol. 2000; 14:401-420. [PubMed: 10707958]

57. Van EE, Verlinden L, Giulietti A, Ramos-Lopez E, Branisteanu DD, Ferreira GB, et al. The vitamin D receptor gene FokI polymorphism: functional impact on the immune system. Eur J Immunol. 2007; 37:395-405. [PubMed: 17274004]

58. Selvaraj P. Vitamin D, vitamin D receptor, and cathelicidin in the treatment of tuberculosis. Vitam Horm. 2011; 86:307-325. [PubMed: 21419277] 
Table 1

The functional effect and associated phenotype of genetic variants in the VDR gene

\begin{tabular}{|c|c|c|c|c|}
\hline SNP & Functional consequence & Medical condition & Treatment & Associated phenotypes \\
\hline \multirow[t]{4}{*}{ rs11568820 } & $\begin{array}{l}\mathrm{A}>\mathrm{G} \text { eliminates } \mathrm{Cdx} \\
\text { binding site }\end{array}$ & $\begin{array}{l}\text { Childhood acute lymphoblastic } \\
\text { leukemia }\end{array}$ & Dexamethasone & $\begin{array}{l}\text { Fat gain, BMD, and apparent } \\
\text { BMD of the lumbar } \\
\text { spine [32] }\end{array}$ \\
\hline & & $\begin{array}{l}\text { X-linked hypophosphatemic ricket } \\
\text { patients }\end{array}$ & 1a-Hydroxyvitamin $\mathrm{D}_{3}$ & $\begin{array}{l}\text { Growth defect and urinary } \\
\text { calcium/keratinise } \\
\text { levels [33] }\end{array}$ \\
\hline & & Prostate cancer risk & Low-calcium diet & Prostate cancer risk [34] \\
\hline & & Psoriasis & Calcipotriol & Calcipotriol response [35] \\
\hline \multirow[t]{2}{*}{ rs4516035 } & $\begin{array}{l}\mathrm{T}>\mathrm{C} \text { eliminates GATA } \\
\text { binding site }\end{array}$ & $\begin{array}{l}\text { Childhood acute lymphoblastic } \\
\text { leukemia }\end{array}$ & Dexamethasone & $\begin{array}{l}\text { Fat gain, BMD and apparent } \\
\text { BMD [32] }\end{array}$ \\
\hline & & $\begin{array}{l}\text { X-linked hypophosphatemic } \\
\text { ricket patients }\end{array}$ & 1a-Hydroxyvitamin $D_{3}$ & $\begin{array}{l}\text { Growth defect and urinary } \\
\text { calcium/keratinise } \\
\text { levels [33] }\end{array}$ \\
\hline \multirow[t]{7}{*}{ rs 2228570} & $\begin{array}{l}\mathrm{T}>\mathrm{C} \text { eliminates } \\
\text { translation } \\
\text { start site }\end{array}$ & Puberty & Not applicable & $\begin{array}{l}\text { Calcium absorption and } \\
\text { calcium accretion to } \\
\text { skeleton [36] }\end{array}$ \\
\hline & & Childhood & Not applicable & $\begin{array}{l}\text { Calcium absorption and BMD } \\
\text { [37] }\end{array}$ \\
\hline & & Osteoporosis or osteopenia & Calcium and vitamin D & $\begin{array}{l}\text { Vitamin D and parathyroid } \\
\text { hormone levels [38] }\end{array}$ \\
\hline & & Psoriasis & Calcipotriol & Calcipotriol response [35] \\
\hline & & Tuberculosis & $\begin{array}{l}\text { Antimycobacterial } \\
\text { chemotherapy }\end{array}$ & $\begin{array}{l}\text { Sputum mycobacterial culture } \\
\text { conversion [39] }\end{array}$ \\
\hline & & Thyroid cancer & VDR agonist & Cell viability [40] \\
\hline & & Breast cancer & 1,25-Dihydroxyvitamin $\mathrm{D}_{3}$ & Growth inhibition [41] \\
\hline \multirow[t]{5}{*}{ rs731236 } & $\mathrm{T}>\mathrm{C}$ methylation site & Psoriasis & Calcipotriol & Calcipotriol response [42] \\
\hline & & Tuberculosis & Not applicable & Tuberculosis susceptibility [43] \\
\hline & & Postmenopausal women & Calcium supplement & New fracture [44] \\
\hline & & Adolescent girls & Vitamin D supplement & $\begin{array}{l}\text { Spine and femoral neck BMC } \\
\text { and femoral neck } \\
\text { area [45] }\end{array}$ \\
\hline & & Chronic plaque psoriasis & $\begin{array}{l}\text { Narrowband ultraviolet } \\
\text { light }\end{array}$ & Remission period [46] \\
\hline \multirow[t]{4}{*}{ rs1544410 } & $\begin{array}{l}\mathrm{C}>\mathrm{T} \text {, unknown functional } \\
\text { consequence }\end{array}$ & Postmenopausal women & Antiresorptive treatment & $\begin{array}{l}\text { BMD, bone formation and } \\
\text { bone resorption [47] }\end{array}$ \\
\hline & & Postmenopausal women & Antisorptive treatment & BMD [48] \\
\hline & & Adolescent girls & Vitamin D supplement & BMC [45] \\
\hline & & Epilesy & Antiepileptic treatment & $\begin{array}{l}\text { BMD, serum } 25- \\
\text { hydroxyvitamin } \mathrm{D}_{3} \text { level and } \\
\text { parathormone level [49] }\end{array}$ \\
\hline rs7975232 & $\begin{array}{l}\mathrm{C}>\mathrm{A} \text {, unknown functional } \\
\text { consequence }\end{array}$ & Colorectal cancer & Dairy product intake & $\begin{array}{l}\text { Colorectal cancer recurrence } \\
\text { [50] }\end{array}$ \\
\hline
\end{tabular}

BMD, bone mineral density; SNP, single nucleotide polymorphism; VDR, vitamin D receptor. 